\title{
DNA Barcoding Ikan Introduksi Khas Telaga Sari, Kabupaten Pasuruan
}

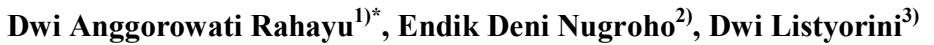 \\ ${ }^{1 *)}$ Jurusan Biologi, Fakultas Matematika dan Ilmu Pengetahuan Alam, Universitas Negeri Surabaya, Jl. Ketintang \\ Gedung C3, Surabaya, Jawa Timur, Indonesia \\ ${ }^{2)}$ Jurusan Biologi, Fakultas Keguruan dan Ilmu Pendidikan, Universitas Borneo Tarakan, Jl. Amal Lama, Tarakan, \\ Kalimantan Utara, Indonesia \\ ${ }^{3)}$ Jurusan Biologi, Fakultas Matematika dan Ilmu Pengetahuan Alam, Universitas Negeri Malang, Jl. Semarang No. 5 \\ Malang, Jawa Timur, Indonesia \\ ${ }^{*}$ Alamat korespondensi: dwirahayu@unesa.ac.id
}

\begin{abstract}
ABSTRAK
Telaga Sari terletak di Purwodadi, Kabupaten Pasuruan yang memiliki kelimpahan jenis ikan introduksi dari Famili Poeciliidae. Anggota Poeciliidae merupakan ikan yang berukuran kecil, live-bearers, memiliki dimorfi seksual dari segi ukuran tubuh dan pola warna. Ikan jantan memiliki gonopodium yang merupakan modifikasi sirip anal, dan ikan betina bunting dan melahirkan. Ikan ini terintroduksi di perairan Indonesia sebagai ikan hias, pengontrol perkembangan nyamuk malaria dan dewasa ini diketahui sebagai model pembelajaran dalam studi biologi. Identifikasi cryptic species menjadi tantangan dalam pengelolaan ikan introduksi baik untuk tujuan konservasi dan budidaya. Penelitian ini bertujuan untuk identifikasi molekuler berdasarkan DNA Barcode COI. Amplifikasi gen target dilakukan dengan menggunakan primer barcode. Analisis identifikasi molekuler melalui kekerabatan pohon filogenetik, similaritas, variasi sekuen DNA, jarak genetik, dan BOLD System. Hasil identifikasi molekuler menunjukkan terbentuk dua klaster besar yang terdiri atas dua klad, spesies yang teridentifikasi sesuai karakter morfologi, yaitu Poecilia reticulata dan Poecilia mexicana dengan indeks kesamaan 90-100\%, sedangkan satu spesies teridentifikasi sebagai Poecilia reticulata $(100 \%$ identik berdasarkan BOLD System) yang seharusnya secara morfologi adalah Xiphoporus helleri. Hasil analisis karakter nukleotida diagnostik ditemukan empat nukleotida untuk Poecilia reticulata, tujuh nukleotida untuk Xiphoporus helleri dan 23 untuk Poecilia mexicana. Diversitas haplotype basa nukleotida sebesar $(\mathbf{0 , 0 0 5 6 6 )}$ yang terbagi menjadi sembilan haplotype dengan empat haplogroup. Ketepatan identifikasi spesies ikan menjadi kunci utama dalam budidaya, perdagangan, manajemen, konservasi, dan perkembangan ilmu pengetahuan.
\end{abstract}

Kata kunci: basa nukleotida diagnostik, DNA Barcode COI, filogenetik, jarak genetik, variasi genetik

\section{DNA Barcoding of Introduced Typical Fishes in Telaga Sari, Pasuruan Regency}

$$
\text { Dwi Anggorowati Rahayu }{ }^{1)^{*}} \text {, Endik Deni Nugroho }{ }^{2)} \text {, Dwi Listyorini }{ }^{3)}
$$

${ }^{1)}$ Department of Biology, Faculty of Mathematics and Natural Sciences, Universitas Negeri Surabaya, Jl. Ketintang C3, Surabaya, East Java, Indonesia

${ }^{2)}$ Department of Biology, Faculty of Education, Universitas Borneo Tarakan, Jl. Amal Lama, Tarakan, North Kalimantan, Indonesia

${ }^{3)}$ Department of Biology, Faculty of Mathematics and Sciences, Universitas Negeri Malang, Jl. Semarang 5 Malang, East Java, Indonesia

${ }^{*}$ Email: dwirahayu@unesa.ac.id

\section{ABSTRACT}

Telaga Sari is located in Purwodadi, Pasuruan Regency which has an abundance of introduced fish species from the Poeciliidae family. Poeciliidae members are small-sized fish, live-bearers, have dimorphism sexual in terms of body size and color patterns. Male fish have gonopodium which is a modification of the anal fin, and pregnant and birthing females. These fish are introduced in Indonesian waters as ornamental fish, controlling the development of malaria mosquitoes and today are known to also play a role as learning models in biological studies. Species identification becomes a new challenge in the management of introduced ornamental fish for conservation and cultivation purposes. The objective of this study was to identify at molecular identification based on DNA Barcode COI. Amplification of target gene was done by using barcode primers. Molecular identification was decided through phylogenetic topology, similarity, sequence variation, 
genetic distance, and BOLD System. Based on molecular identification showed two large clusters consisting of two clades, species identified according to morphological characters, namely Poecilia reticulata and Poecilia mexicana with similarity index $\mathbf{9 0 - 1 0 0 \%}$. One species identified as Poecilia reticulata $(100 \%$ identical based on the Bold System) which should be morphologically Xiphoporus helleri. Analysis of nucleotide diagnostic characters showed that Poecilia reticulata has four nucleotides, Xiphoporus helleri seven nucleotides and Poecilia mexicana 23 nucleotides. The haplotype diversity is $(\mathbf{0 . 0 0 5 6 6 )}$ which is divided into nine haplotypes belong to 4 haplogroup. The corret identification of fish species is a useful tool for aquaculture, trade, management, conservation and development of science.

Keywords: diagnostic sequence, DNA Barcode COI, phylogenetic, genetic distance, genetic variation

\section{PENDAHULUAN}

Telaga Sari Purwodadi, Kabupaten Pasuruan merupakan telaga kecil yang memiliki keanekaragaman ikan introduksi yang melimpah, yaitu ikan anggota Poeciliidae. Anggota Famili Poeciliidae terdiri dari tiga sub famili, yaitu Poeciliinae (220 spesies), Procatopodinae (78 spesies), dan Aplocheilichthyinae (satu spesies) [1]. Famili Poeciliidae merupakan ikan yang tersebar luas hampir di seluruh belahan dunia mulai dari Afrika, China, Turki, Prancis, Mexico, Inggris, Vietnam, Malaysia, Spanyol, Portugis, Belanda, Denmark, Polandia, Rusia, Albania, dan Jepang, termasuk di Indonesia [2]. Namun ikan ini merupakan ikan endemik negara Amerika, Australia Mexico, dan Kanada [3,4,5] yang kini keberadaannya melimpah di Indonesia. Introduksi dan distribusi ikan introduksi ke dalam perairan dianggap menjadi salah satu penyebab utama ancaman keragaman ikan di alam $[6,7,8]$, terutama bagi jenis ikan yang mendiami perairan tawar [3]. Kelimpahan ikan air tawar diduga keberadaanya menjadi faktor utama dalam penyebaran ikan introduksi dari satu lokasi ke lokasi lainnya bahkan sebagian dari ikan tersebut telah tercatat sebagai invasive alien species [9].

Anggota Famili Poeciliidae merupakan ikan yang berukuran kecil (panjang total antara 4-20 cm), ciri diagnostiknya yaitu (1) jari- jari ke- 3, 4, dan 5 dari sirip anal mengalami modifikasi menjadi gonopodium [10]; (2) fertilisasinya secara internal (ikan jantan memasukkan sperma ke dalam organ genital betina); (3) bunting dan melahirkan (live bearers) [3,11]. Selain itu, karakter lain yang dimiliki oleh ikan yang tergolong Poeciliidae adalah hanya mempunyai satu sirip punggung yang merupakan jari-jari lunak, jari-jari sirip anal pada ikan betina berjumlah A9, jari-jari ketiga sirip anal tersebut tidak bercabang, bentuk sirip ekor rounded atau emarginated, jari-jari sirip perut berjumlah V6, sirip dada memiliki jari-jari lunak P9-16, menunjukkan dimorfi seksual dari segi ukuran tubuh dan pola warna, serta memiliki sisik sikloid [9]. Anggota ikan ini berperan sebagai objek atau model pembelajaran dalam studi biologi seperti: ekologi, anatomi, embriologi, morfologi, fisiologi, dan tingkah laku [3]. Beberapa ikan anggota Famili Poeciliidae ini memiliki keunggulan sebagai pengontrol perkembangan nyamuk malaria [11]. Namun, kajian sistematik, keanekaragaman, dan hubungan kekerabatan (Phylogenetic relationship) di antara genus masih kurang [3].

Kemelimpahan ikan introduksi di Telaga

Sari Purwodadi, Kabupaten Pasuruan menjadikan ikan ini menarik untuk diteliti. Hal ini dikarenakan dalam satu danau hanya ditemukan ikan Famili Poeciliidae tersebut dalam jumlah melimpah dan tidak ditemukan jenis ikan lokal lainnya. Kemelimpahan ikan ini tidak didukung dengan pengenalan masyarakat sekitar terkait potensi ikan tersebut di alam. Rahayu et al. [12] menyatakan secara genetik berdasarkan gen 16S rRNA ikan introduksi yang berada di Telaga Sari merupakan Famili Poeciliidae, namun belum sampai teridentifikasi di tingkat spesies. Dari penelitian tersebut terdapat hal yang sangat mengejutkan bahwa ikan gatul dari Telaga Sari memiliki hubungan kekerabatan yang sangat jauh (outgroup) dengan Poecilia reticulata yang merupakan satu famili yaitu Poeciliidae. Belum diketahuinya secara pasti status taksonomi ikan introduksi tersebut membuat pentingnya dilaksanakannya penelitian lanjutan terkait status taksonomi ikan ini dalam upaya pengelolaan, budidaya dan konservasi keberlanjutannya. Dugaan awal susahnya identifikasi ikan introduksi tersebut dikarenakan adanya fenomena cryptic spesies, sehingga identifikasi ikan tersebut sulit dilakukan.

Kesesuaian dan ketepatan identifikasi spesies merupakan masalah utama dalam pengelolaan sumber daya ikan, baik ikan introduksi maupun endemik. Frankham et al. [13] menyebutkan bahwa status taksonomi ikan merupakan tahap awal konservasi biologi. Saat 
ini, semakin berkembangnya teknologi di bidang biologi molekuler menjadikan terobosan baru identifikasi spesies menggunakan marka genetik. Taylor \& Harrist [14] menyebutkan bahwa identifikasi taksonomi, penentuan jenis spesies dan pengelompokannya dapat dilakukan melalui DNA Barcoding. Lebih lanjut Hebert et al. [15] menjelaskan bahwa gen cytochrome oxydase oxidase sub unit I (COI) merupakan barcode genetik untuk semua makhluk hidup yang belum diketahui jenisnya. Peran DNA Barcode dalam studi taksonomi ikan dapat diaplikasikan pada semua tingkatan stadia dari telur hingga dewasa [16].

Gen COI memiliki dua keunggulan utama yaitu, (1) primer-primer universal untuk gen ini memiliki kemampuan sangat kuat, yaitu mampu mencakup ujung 5' dari sebagian besar atau keseluruhan filum hewan [16, 17]; (2) gen COI memiliki rentangan sinyal filogenetik yang lebih besar dibandingkan dengan gen mitokondrial lainnya. Evolusi pada gen ini cukup cepat untuk menunjukkan perbedaan tidak hanya untuk spesies yang berkerabat dekat, tetapi juga antara kelompok geography dalam suatu spesies tunggal [18]. Gen COI ini sudah digunakan untuk identifikasi ikan air tawar di Kanada [19]; ikan laut di Australia termasuk di dalamnya ikan teleost, hiu dan pari [20]; dan ikan air tawar dari Mexico dan Guatemala [21]. Selain itu, gen tersebut juga digunakan untuk identifikasi larva ikan yang hidup di perairan Australia, dan identifikasi ikan sebelum tahap dewasa yang mencakup perkembangan mulai dari telur sampai tahap dewasa [22, 23]. Penggunaan DNA barcode dalam identifikasi spesies ikan introduksi salah satunya telah dilakukan oleh Collins et al. [24] dengan mengidentifikasi ikan hias introduksi yang terdiri atas 172 spesies Cyprinid. Ikan introduksi tersebut digemari oleh masyarakat dan beredar sangat luas di pasar ikan hias internasional, seperti jenis danio, rasbora, barb, puntius, dan lain-lain.

Mengacu pada fenomena cyptic species dan belum adanya kejelasan status taksonomi ikan Famili Poeciliidae yang mendiami Telaga Sari, Pasuruan, maka perlu dilakukan upaya assessment secara cepat melalui identifikasi molekuler dengan menggunakan marka DNA Barcoding. Penelitian ini dilakukan untuk mengidentifikasi jenis ikan introduksi Famili Poeciliidae melalui identifikasi molekuler meliputi kekerabatan pohon filogenetik, similaritas, variasi sekuen DNA, jarak genetik, dan BOLD System.

\section{METODE PENELITIAN}

Koleksi sampel. Koleksi sampel dilakukan di Telaga Sari, Purwodadi, Kabupaten Pasuruan. Sampel ikan ditangkap dengan menggunakan jaring lempar. Ikan yang tertangkap didokumentasikan selanjutnya disimpan dalam formalin untuk proses identifikasi karakter morfometrik, meristrik dan karakter diagnostik $[25 ; 26]$ dan sebagian lagi disimpan dalam alkohol pure grade untuk identifikasi molekuler.

Ekstraksi dan amplifikasi DNA. Isolasi DNA total dari sampel sirip dada dilakukan dengan menggunakan DNA Isolation Kit (NucleoSpin ${ }^{\circledR} \quad$ Tissue, Macherey-Nagel, Germany) dan mengikuti prosedur dari NucleoSpin ${ }^{\circledR} \quad$ Tissue dengan beberapa modifikasi. Hasil DNA murni yang didapatkan diukur menggunakan UV spektrofotometer NANO DROP 2000. Kalibrasi dilakukan menggunakan buffer elution (BE) yang merupakan pelarut stok DNA. Setelah didapatkan DNA murni, maka tahap selanjutnya yaitu kloning gen cytochrome-c oxidase I (COI) dengan teknik PCR menggunakan primer barcording khusus gen COI $[17 ; 15 ; 27]$ yaitu:

COI Barcoding Forward 5'-
GGTCAACAAATCATAAAGATATTGG-3', COI Barcoding Reverse 5' TAAACTTCAGGGTGACCAAAAAATCA-3'. Berdasarkan jumlah DNA total yang didapatkan, reaksi PCR dilakukan dalam volume $50 \mu \mathrm{l}$ (mengikuti prosedur iNtRON BIOTECHNOLOGY) dengan siklus sebagai berikut amplifikasi PCR dilakukan dalam 40 siklus, denaturasi awal pada suhu $94^{\circ} \mathrm{C}$ selama 2 menit, denaturasi pada suhu $94^{\circ} \mathrm{C}$ selama 45 detik, annealing dengan suhu $45^{\circ} \mathrm{C}$ selama 45 detik, pemanjangan pada suhu $72^{\circ} \mathrm{C}$ selama 1,5 menit, pemanjangan akhir pada suhu $72^{\circ} \mathrm{C}$ selama 10 menit. Siklus ini diulang sebanyak 40x. Setelah PCR, pengecekan keberhasilan amplifikasi PCR dilakukan melalui elektroforesis. Setelah muncul suspect band pada hasil elektroforesis, hasil PCR disekuensing melalui Big Dye Terminator ABI 3130 xl. Proses sekuensing dilakukan di Eijkman Institute for Molecular Biology Jakarta. 
Tabel 1. Kode sampel dengan Kerabatnya dari GenBank dan BOLD System

\begin{tabular}{|c|c|c|c|c|}
\hline No & Nama Sampel & Lokasi Sampel & $\begin{array}{c}\text { Acc Number Gene } \\
\text { Bank }\end{array}$ & $\begin{array}{l}\text { Acc Number Bold } \\
\text { System }\end{array}$ \\
\hline 1 & Xiphophorus helleri 1 & $\begin{array}{l}\text { Telaga Sari, } \\
\text { Purwodadi, } \\
\text { Pasuruan }\end{array}$ & Sampel penelitian & Sampel penelitian \\
\hline 2 & Xiphophorus helleri 1 & $\begin{array}{l}\text { Telaga Sari, } \\
\text { Purwodadi, } \\
\text { Pasuruan }\end{array}$ & Sampel penelitian & Sampel penelitian \\
\hline 3 & Xiphophorus helleri 2 & $\begin{array}{l}\text { Telaga Sari, } \\
\text { Purwodadi, } \\
\text { Pasuruan }\end{array}$ & Sampel penelitian & Sampel penelitian \\
\hline 4 & Xiphophorus helleri 2 & $\begin{array}{l}\text { Telaga Sari, } \\
\text { Purwodadi, } \\
\text { Pasuruan }\end{array}$ & Sampel penelitian & Sampel penelitian \\
\hline 5 & Poecilia mexicana & $\begin{array}{l}\text { Telaga Sari, } \\
\text { Purwodadi, } \\
\text { Pasuruan }\end{array}$ & Sampel penelitian & Sampel penelitian \\
\hline 6 & Poecilia mexicana & $\begin{array}{l}\text { Telaga Sari, } \\
\text { Purwodadi, } \\
\text { Pasuruan }\end{array}$ & Sampel penelitian & Sampel penelitian \\
\hline 7 & Poecilia reticulata & $\begin{array}{l}\text { Telaga Sari, } \\
\text { Purwodadi, } \\
\text { Pasuruan }\end{array}$ & Sampel penelitian & Sampel penelitian \\
\hline 8 & Poecilia reticulata & $\begin{array}{l}\text { Telaga Sari, } \\
\text { Purwodadi, } \\
\text { Pasuruan }\end{array}$ & Sampel penelitian & Sampel penelitian \\
\hline 9 & $\begin{array}{l}\text { Xiphophorus hellerii } \\
\text { voucher MXIV0344 }\end{array}$ & Kanada & HQ573209.1 & MFIV062-10.COI-5P \\
\hline 10 & $\begin{array}{l}\text { Xiphophorus hellerii } \\
\text { voucher MXIII381 }\end{array}$ & Kanada & GU807092.1 & MXIII338-09.COI-5P \\
\hline 11 & $\begin{array}{l}\text { Xiphophorus hellerii } \\
\text { voucher KW11T085 }\end{array}$ & Kanada & KU569081.1 & FWAQ072-11.COI-5P \\
\hline 12 & $\begin{array}{l}\text { Xiphophorus hellerii } \\
\text { voucher BIF2926 }\end{array}$ & Kanada & KU692952.1 & BIFD2486-14.COI-5P \\
\hline 13 & $\begin{array}{l}\text { Poecilia mexicana } \\
\text { voucher stri2 } 2074\end{array}$ & Amerika & JX968678.1 & BOLD:ACR5435 \\
\hline 14 & $\begin{array}{l}\text { Poecilia mexicana } \\
\text { voucher SA9 }\end{array}$ & Amerika & JX968663.1 & BOLD:AAA4518 \\
\hline 15 & $\begin{array}{l}\text { Poecilia reticulata } \\
\text { voucher KW11T027 }\end{array}$ & Afrika Selatan & KU568971.1 & FWAQ014-11.COI-5P \\
\hline 16 & $\begin{array}{l}\text { Poecilia reticulata } \\
\text { voucher Ex } 51 \mathrm{H} 4\end{array}$ & German & KM287034.1 & $\begin{array}{l}\text { FFMBH2593-14.COI- } \\
\text { 5P }\end{array}$ \\
\hline 17 & $\begin{array}{l}\text { Cyprinodontiformes sp. } \\
\text { BOLD:AAA6554 } \\
\text { voucher MXIII408 }\end{array}$ & Kanada & GU672713.1 & MXIII365-09.COI-5P \\
\hline
\end{tabular}

Analisis data. Analisis data genetik dilakukan berdasarkan hasil pembacaan kromatogram (Finch TV) dari sekuen Barcode COI ( $\pm 500 \mathrm{bp})$. Setelah dicek dengan software Finch TV, selanjutnya dianalisis dengan menggunakan DNASTAR untuk melihat kromatogram sekuen dan membuat consensus (menggabungkan primer foward dan reverse).
Hasil consensus dicocokkan dengan BLAST secara online, tujuannya adalah untuk mengetahui kecocokan gen target dengan Query yang diperoleh dari Gene Bank dan BOLD System. Sebelum tahap alignment, setiap sampel ditranslasi menjadi protein (tanpa adanya stop kodon di bagian tengah/numt) dengan menggunakan DNASTAR. Tahap selanjutnya 
yaitu alignment dengan menggunakan Clustal $W$ di Mega 6 [28] selanjutnya diperiksa secara manual menggunakan Bioedit ver 7.0.9. Hasil alignment kemudian dicek satu per satu untuk identifikasi secara online pada BOLD System (www.barcodinglife.org) dan cek similaritas melalui GenBank serta dibandingkan dengan kerabatnya pada genbank (Tabel 1). Selanjutnya, membuat konstruksi topologi filogenetik untuk mengetahui hubungan kekerabatan antara spesies satu dan spesies lainnya dengan menggunakan program komputer Mega 6 dengan metode Maximum Parsimony (MP), Maximum Likelihood (ML) dan Neighbour Joining (NJ) dengan model perhitungan algoritmik Kimura-2 parameter (lebih efektif untuk barcoding, karena opsi tersebut mempertimbangkan titik substitusi transisi dan transversi) serta menghitung jarak genetik intra dan inter spesies [29]. Evaluasi pohon dilakukan dengan menggunakan analisis bootstrap sebanyak 1000 ulangan. Perhitungan nilai similaritas yaitu Persentase Similaritas $=(1$ Jarak Genetik) x 100\%. Analisis variasi sekuen basa nukleotida dan haplotype antara Famili Poeciliidae dilakukan dengan menggunakan program komputer DnaSP v.5.0, serta membuat haplogroup berdasarkan analisis median joining network Famili Poeciliidae dengan kerabatnya berdasarkan haplotype menggunakan program komputer Network 4.1.0.8 [30].

\section{HASIL DAN PEMBAHASAN}

Identifikasi melalui BOLD System. Sejumlah 556 basa nukleotida telah berhasil ditranslasi menjadi protein tanpa ditemukan adanya stop kodon di tengah sekuen (pseudogen) di antara delapan sampel yang telah dilakukan sekuensing. Basa nukleotida tersebut kemudian dianalisis lebih lanjut dengan identifikasi online melalui BOLD System (Tabel 2). Kesamaan dari kelompok Poecilia mexicana dengan data Bold System sangat tinggi antara 99,20-99,33\%, begitu juga dengan Poecilia reticulata sebesar 99,20-99,50\%. Kesamaan tinggi antara Xiphoporus helerii sampel dengan Poecilia reticulata disebabkan karena kesalahan pemberian nama pada data base BOLD System. Setelah dilakukan cek sampel berdasarkan kode spesimen (voucher) pada BOLD System, spesimen tersebut merupakan karakter dari kelompok genus Xiphoporus yaitu adanya ekor pedang pada spesies jantan dan terlihat adanya gonopodium (modifikasi sirip anal) [10]. Sehingga dapat disimpulkan bahwa sampel Xiphoporus helleri yang ditemukan di Telaga Sari, Pasuruan merupakan Xiphoporus helerri menggunakan DNA Barcode COI dengan indeks similaritas sebesar 98,82-100\% dengan BOLD System. Hal ini juga didukung dari asal usul data BOLD yaitu Amerika dan Afrika Selatan yang merupakan habitat asli dari kelompok Famili Poeciliidae. Aringthon [33] menyatakan bahwa ikan anggota Famili Poeciliidae bersifat eurytermic. Famili Poeciliidae merupakan ikan yang mampu hidup pada rentang suhu yang besar, dan kemampuan beradaptasi dengan lingkungan baru menjadikan kesuksesan ikan introduksi tersebut untuk bertahan. Hal ini sejalan dengan data yang dirilis oleh Global Invasive Species Database (http://www.iucngisd.org/gisd/) terdata bahwa spesies yang ditemukan memiliki potensi sebagai invasive alien species (menginvasi lingkungan).

Penelitian ini menambahkan data ikanikan yang mendiami perairan Indonesia, khususnya Telaga Sari Pasuruan pada perpustakaan DNA barcoding (BOLD System). Dengan mengikuti persyaratan yang telah dikeluarkan oleh GenBank, yaitu (1) memiliki sekuen nukleotida sepanjang 500 bp berasal dari situs barcoding gen COI, (2) amplifikasi mengacu pada primer yang telah ditentukan oleh konsorsium, (3) rekam jejak file dapat diakses secara terbuka, dan (4) penamaan spesies telah mengacu pada dokumen yang telah disepakati. Melalui BOLD System, permasalahan status taksonomi ikan yang mendiami perairan Indonesia (baik lokal, endemik, maupun introduksi) dapat terselesaikan secara cepat, tepat dan akurat [15].

Variasi basa nukleotida. Kekhawatiran saat menggunakan marker DNA mitokondria untuk amplifikasi adalah adanya "COI like sequence" atau pseudogen yang berasal dari mitokondria (numt) [31]. Untuk mengonfirmasi urutan ini benar-benar berasal dari gen COI DNA mitokondria atau bukan, kami melakukan beberapa analisis lanjut. Salah satunya yaitu identifikasi adanya karakter numt, adanya penyisipan dan penghapusan dalam urutan DNA (NUMTs) [32]. Namun, hasil dari penyelarasan gen COI Famili Poeciliidae dalam penelitian ini tidak ditemukan adanya insersi dan delesi (indel). Selain itu, untuk memastikan adanya numt, telah diperiksa secara cermat heterozigositas peak puncak kromatogram [31], 
dan urutan yang diperoleh tidak tumpang tindih. Jadi bisa dipastikan sekuen DNA yang telah teramplifikasi dalam penelitian ini adalah gen COI pada DNA mitokondria.

Tabel 2. Tiga nilai kecocokan tertinggi dari identifikasi melalui BOLD System dengan representasi nilai similaritas

\begin{tabular}{ccc}
\hline Nama spesimen & Identifikasi BOLD (3 tertinggi) & Similaritas (\%) \\
\hline Xiphophorus helleri 1 & Poecilia reticulata & 100 \\
& Poecilia reticulata & 99,98 \\
& Poecilia reticulata & 99,94 \\
Xiphophorus helleri 1 & Poecilia reticulata & 99,84 \\
& Poecilia reticulata & 99,84 \\
& Poecilia reticulata & 99,84 \\
Xiphophorus helleri 2 & Poecilia reticulata & 98,82 \\
& Poecilia reticulata & 98,82 \\
\multirow{5}{*}{ Xiphophorus helleri 2 } & Poecilia reticulata & 98,82 \\
& Poecilia reticulata & 98,82 \\
Poecilia mexicana & Poecilia reticulata & 98,82 \\
& Poecilia reticulata & 98,82 \\
& Poecilia mexicana & 99,33 \\
Poecilia mexicana & Poecilia mexicana & 99,33 \\
& Poecilia mexicana & 99,33 \\
& Poecilia mexicana & 99,20 \\
Poecilia reticulata & Poecilia mexicana & 99,20 \\
& Poecilia mexicana & 99,20 \\
Poecilia reticulata & Poecilia reticulata & 99,50 \\
& Poecilia reticulata & 99,50 \\
& Poecilia reticulata & 99,50 \\
& Poecilia reticulata & 99,20 \\
& Poecilia reticulata & 99,20 \\
& Poecilia reticulata & 99,20 \\
\hline
\end{tabular}

Tabel 3. Variasi basa nukleotida, tipe mutasi dan komposisi basa nukleotida gen COI

\begin{tabular}{|c|c|c|c|c|c|c|c|c|}
\hline \multirow[t]{2}{*}{ Spesies } & \multirow{2}{*}{$\begin{array}{l}\text { Conserved } \\
\text { sites }\end{array}$} & \multicolumn{2}{|c|}{ Variasi } & \multirow{2}{*}{$\begin{array}{c}\text { Variable } \\
\text { sites }\end{array}$} & \multirow[t]{2}{*}{ si } & \multirow[t]{2}{*}{ sv } & \multicolumn{2}{|c|}{$\begin{array}{c}\text { Komposisi basa } \\
\text { nukleotida }\end{array}$} \\
\hline & & $\mathrm{Pi}$ & $\mathrm{S}$ & & & & AT & $\mathrm{GC}$ \\
\hline Gen COI & & & & & & & & \\
\hline Xiphoporus helleri 1 & 556 & 4 & 6 & 10 & 7 & 3 & $57,37 \%$ & $42,63 \%$ \\
\hline Xiphoporus helleri 2 & 556 & 4 & 6 & 10 & 7 & 3 & $57,37 \%$ & $42,63 \%$ \\
\hline Poecilia mexicana & 556 & 16 & 7 & 23 & 18 & 5 & $55,94 \%$ & $44,06 \%$ \\
\hline Poecilia reticulata & 556 & 2 & 2 & 4 & 3 & 1 & $57,55 \%$ & $42,45 \%$ \\
\hline Semua sampel & 556 & 21 & 10 & 31 & 22 & 9 & $57,55 \%$ & $42,45 \%$ \\
\hline
\end{tabular}

Keterangan: Pi: Parsimony-informative site, s: singleton site, si: transition pair, sv: transversi pair

Tabel 4. Variasi basa nukleotida Famili Poecilidae berdasarakan gen COI serta Nukleotida penciri (automophi) Famili Poeciliidae

\begin{tabular}{|c|c|c|c|c|c|c|c|c|c|c|c|c|c|c|c|c|c|c|c|c|c|c|c|}
\hline \multirow{2}{*}{ Spesimen } & \multicolumn{23}{|c|}{ Variasi Basa Nukleotida } \\
\hline & 0 & $\because$ & $\vec{\sim}$ & ป & $\stackrel{\mathbb{N}}{ }$ & $\approx$ & $m$ & r & 8 & ชె & 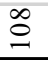 & $\Xi$ & $\stackrel{8}{n}$ & $\hat{n}$ & $\stackrel{ \pm}{I}$ & $\stackrel{\infty}{-1}$ & ָิ & $\hat{\text { i }}$ & సે & $\stackrel{\mathfrak{d}}{\sim}$ & $\tilde{n}$ & $\stackrel{\cong}{\sim}$ & तె \\
\hline Poecilia reticulata & $\mathrm{C}$ & $\mathrm{C}$ & $\mathrm{C}$ & $\mathrm{C}$ & $\mathrm{T}$ & $\mathrm{T}$ & G & $\mathrm{A}$ & $\mathrm{T}$ & $\mathrm{T}$ & $\mathrm{C}$ & $\mathrm{A}$ & $\mathrm{C}$ & $\mathrm{C}$ & $\mathrm{C}$ & $\mathrm{A}$ & $\mathrm{T}$ & $\mathrm{A}$ & $\mathrm{T}$ & G & $\mathrm{C}$ & $\mathrm{T}$ & $\mathrm{T}$ \\
\hline Poecilia reticulata & $\cdot$ & . & . & . & . & . & . & . & & . & . & . & . & . & . & . & . & . & . & $\cdot$ & . & . & . \\
\hline Xiphoporus helerii 2 & $\mathrm{~T}$ & . & G & A & G & G & . & $\cdot$ & & $\mathrm{C}$ & . & . & . & $\mathrm{T}$ & $\cdot$ & & . & G & . & . & $\mathrm{T}$ & $\cdot$ & \\
\hline Xiphoporus helerii 2 & $\mathrm{~T}$ & . & G & $\mathrm{A}$ & G & G & . & $\cdot$ & & $\mathrm{C}$ & . & . & . & $\mathrm{T}$ & . & & . & G & . & . & $\mathrm{T}$ & . & . \\
\hline Xiphoporus helerii 1 & $\mathrm{~T}$ & . & G & A & G & G & . & . & & $\mathrm{C}$ & . & . & . & $\mathrm{T}$ & . & . & . & G & . & . & $\mathrm{T}$ & . & . \\
\hline Xiphoporus helerii 1 & $\mathrm{~T}$ & . & G & A & G & G & . & . & & $\mathrm{C}$ & . & . & . & $\mathrm{T}$ & . & . & . & G & . & . & $\mathrm{T}$ & . & \\
\hline Poecilia mexicana & . & $\mathrm{T}$ & A & $\mathrm{T}$ & A & . & A & $\mathrm{T}$ & $\mathrm{C}$ & . & $\mathrm{T}$ & $\mathrm{C}$ & $\mathrm{T}$ & . & A & G & $\mathrm{C}$ & $\mathrm{T}$ & G & A & . & $\mathrm{C}$ & $\mathrm{C}$ \\
\hline Poecilia mexicana & & $\mathrm{T}$ & $\mathrm{A}$ & $\mathrm{T}$ & A & . & A & $\mathrm{T}$ & $\mathrm{C}$ & - & $\mathrm{T}$ & $\mathrm{C}$ & $\mathrm{T}$ & . & A & $\mathrm{G}$ & $\mathrm{C}$ & $\mathrm{T}$ & $\mathrm{G}$ & A & . & $\mathrm{C}$ & $\mathrm{C}$ \\
\hline
\end{tabular}




\begin{tabular}{|c|c|c|c|c|c|c|c|c|c|c|}
\hline \multirow[b]{2}{*}{ Spesimen } & \multicolumn{10}{|c|}{ Variasi Basa Nukleotida } \\
\hline & $\stackrel{n}{\sim}$ & $\begin{array}{l}\stackrel{\sim}{+} \\
\stackrel{m}{2}\end{array}$ & $\underset{f}{\stackrel{f}{f}}$ & $\stackrel{n}{q}$ & $\begin{array}{l}\infty \\
\dot{f}\end{array}$ & $\underset{+}{\stackrel{+}{+}}$ & ๙ু & in & $\frac{a}{n}$ & $\underset{\sim}{\sim}$ \\
\hline Poecilia reticulata & $\mathrm{T}$ & $\mathrm{T}$ & $\mathrm{A}$ & $\mathrm{A}$ & $\mathrm{C}$ & $\mathrm{G}$ & $\mathrm{T}$ & $\mathrm{A}$ & $\mathrm{T}$ & $\mathrm{G}$ \\
\hline Poecilia reticulata & & . & . & . & . & . & . & . & . & \\
\hline Xiphoporus helerii 2 & . & . & . & . & A & . & . & . & . & \\
\hline Xiphoporus helerii 2 & . & . & . & . & A & . & . & . & . & . \\
\hline Xiphoporus helerii 1 & . & . & . & . & $\mathrm{A}$ & . & . & . & . & . \\
\hline Xiphoporus helerii 1 & . & . & . & . & $\mathrm{A}$ & . & . & . & . & . \\
\hline Poecilia mexicana & $\mathrm{C}$ & $\mathrm{C}$ & $\mathrm{C}$ & G & $\mathrm{T}$ & A & A & $\mathrm{T}$ & $\mathrm{G}$ & $\mathrm{A}$ \\
\hline Poecilia mexicana & $\mathrm{C}$ & $\mathrm{C}$ & $\mathrm{C}$ & $\mathrm{G}$ & $\mathrm{T}$ & A & A & $\mathrm{T}$ & $\mathrm{G}$ & A \\
\hline
\end{tabular}

Tabel 5. Jarak genetik antar grup (OTU) ikan Famili Poeciliidae berdasarkan sekuen Barcode gen COI menggunakan model perhitungan $p$-distance (Persentase)

\begin{tabular}{|c|c|c|c|c|c|c|c|c|c|c|c|c|c|c|c|c|c|c|}
\hline & & 1 & 2 & 3 & 4 & 5 & 6 & 7 & 8 & 9 & 10 & 11 & 12 & 13 & 14 & 15 & 16 & 17 \\
\hline 1 & Poecilia mexicana & & & & & & & & & & & & & & & & & \\
\hline 2 & Poecilia mexicana & 0 & & & & & & & & & & & & & & & & \\
\hline 3 & JX968663.1 Poecilia mexicana & 0 & 0 & & & & & & & & & & & & & & & \\
\hline 4 & JX968678.1 Poecilia mexicana & 1.3 & 1.3 & 1.3 & & & & & & & & & & & & & & \\
\hline 5 & Poecilia reticulata & 13.2 & 13.2 & 13.2 & 14 & & & & & & & & & & & & & \\
\hline 6 & Poecilia reticulata & 13.2 & 13.2 & 13.2 & 14 & 0 & & & & & & & & & & & & \\
\hline 7 & Xiphoporus hellerii 2 & 12.9 & 12.9 & 13.2 & 13.6 & 1.1 & 1.1 & & & & & & & & & & & \\
\hline 8 & Xiphoporus hellerii 2 & 12.9 & 12.9 & 12.9 & 13.6 & 1.1 & 1.1 & 0 & & & & & & & & & & \\
\hline 9 & Xiphoporus hellerii 1 & 12.9 & 12.9 & 12.9 & 13.6 & 1.1 & 1.1 & 0 & 0 & & & & & & & & & \\
\hline 10 & Xiphoporus hellerii 1 & 12.9 & 12.9 & 12.9 & 13.6 & 1.1 & 1.1 & 0 & 0 & 0 & & & & & & & & \\
\hline 11 & KM287034.1 Poecilia reticulata voucher Ex $51 \mathrm{H} 4$ & 13.1 & 13.1 & 13.1 & 13.8 & 5.4 & 5.4 & 4.5 & 4.5 & 4.5 & 4.5 & & & & & & & \\
\hline 12 & KU568971.1 Poecilia reticulata voucher KW11T027 & 13.4 & 13.4 & 13.4 & 14.2 & 6 & 6 & 5.1 & 5.1 & 5.1 & 5.1 & 0.5 & & & & & & \\
\hline 13 & KU692952.1 Xiphoporus hellerii voucher BIF2926 & 16.2 & 16.2 & 16.2 & 16.3 & 17.6 & 17.6 & 17.1 & 17.1 & 17.1 & 17.1 & 15.1 & 14.9 & & & & & \\
\hline 14 & KU569081.1 Xiphoporus hellerii voucher KWIII408 & 16.2 & 16.2 & 16.2 & 16.3 & 17.6 & 17.6 & 17.1 & 17.1 & 17.1 & 17.1 & 15.1 & 14.9 & 0 & & & & \\
\hline 15 & GU807092.1 Xiphoporus hellerii voucher MXIII408 & 16.3 & 16.3 & 16.3 & 16.5 & 17.6 & 17.8 & 17.2 & 17.2 & 17.2 & 17.2 & 15.2 & 15.1 & 0.2 & 0.2 & & & \\
\hline 16 & HQ573209.1 Xiphoporus hellerii voucher MXIV0344 & 16.2 & 16.2 & 16.2 & 16.3 & 17.8 & 17.6 & 17.2 & 17.1 & 17.1 & 17.1 & 14.9 & 14.9 & 0 & 0 & 0.2 & & \\
\hline 17 & GU672713.1 Cyprinodontiformes sp. BOLD AAA654 & 19.2 & 19.2 & 19.2 & 18.9 & 23 & 23 & 22.7 & 22.7 & 22.7 & 22.7 & 23.6 & 23.6 & 20 & 0.2 & 20 & 20 & \\
\hline
\end{tabular}

Tabel 6. Persentase Jarak genetik intra dan interspesies berdasarka model K2P

\begin{tabular}{lccc}
\hline \multicolumn{1}{c}{ Jarak Genetik } & $\begin{array}{c}\text { Poecilia } \\
\text { reticulata }\end{array}$ & Poecilia mexicana & Xiphoporus hellerii \\
\hline Gen COI & 0 & 0 & 0 \\
Jarak minimum intraspesies & 0.1 & 1.3 & 0.2 \\
Jarak maksimum & & 1.3 & 1.1 \\
intraspesies & 0.5 & 18.7 & \\
Rata-rata jarak intraspesies & & & \\
Rata-rata jarak interspesies & &
\end{tabular}




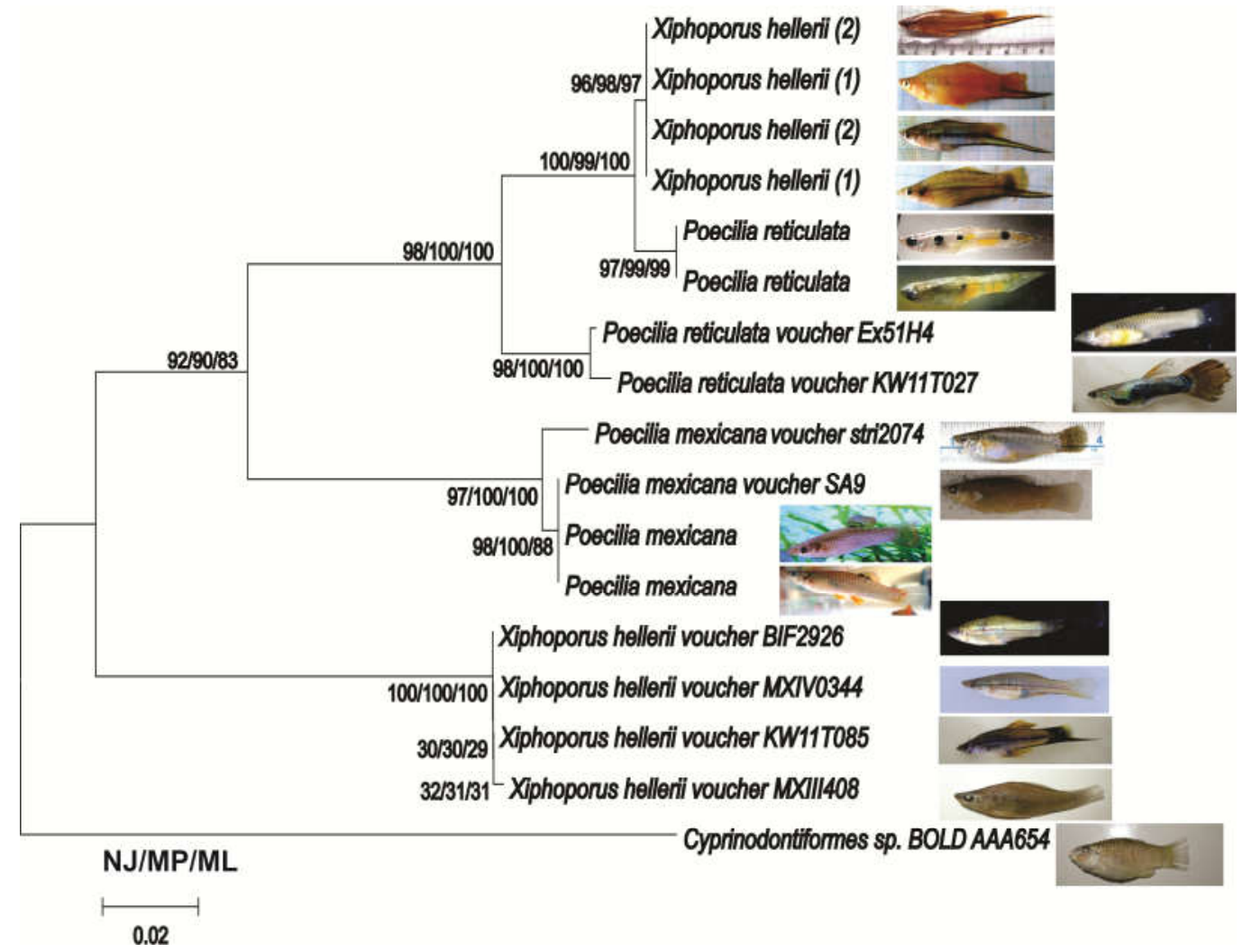

Gambar 1. Topologi filogenetik Famili Poeciliidae dari Telaga Sari, Pasuruan dengan referensi gen COI dari gene bank (NJ, MP dan ML dengan bootstrap 1000 kali ulangan)

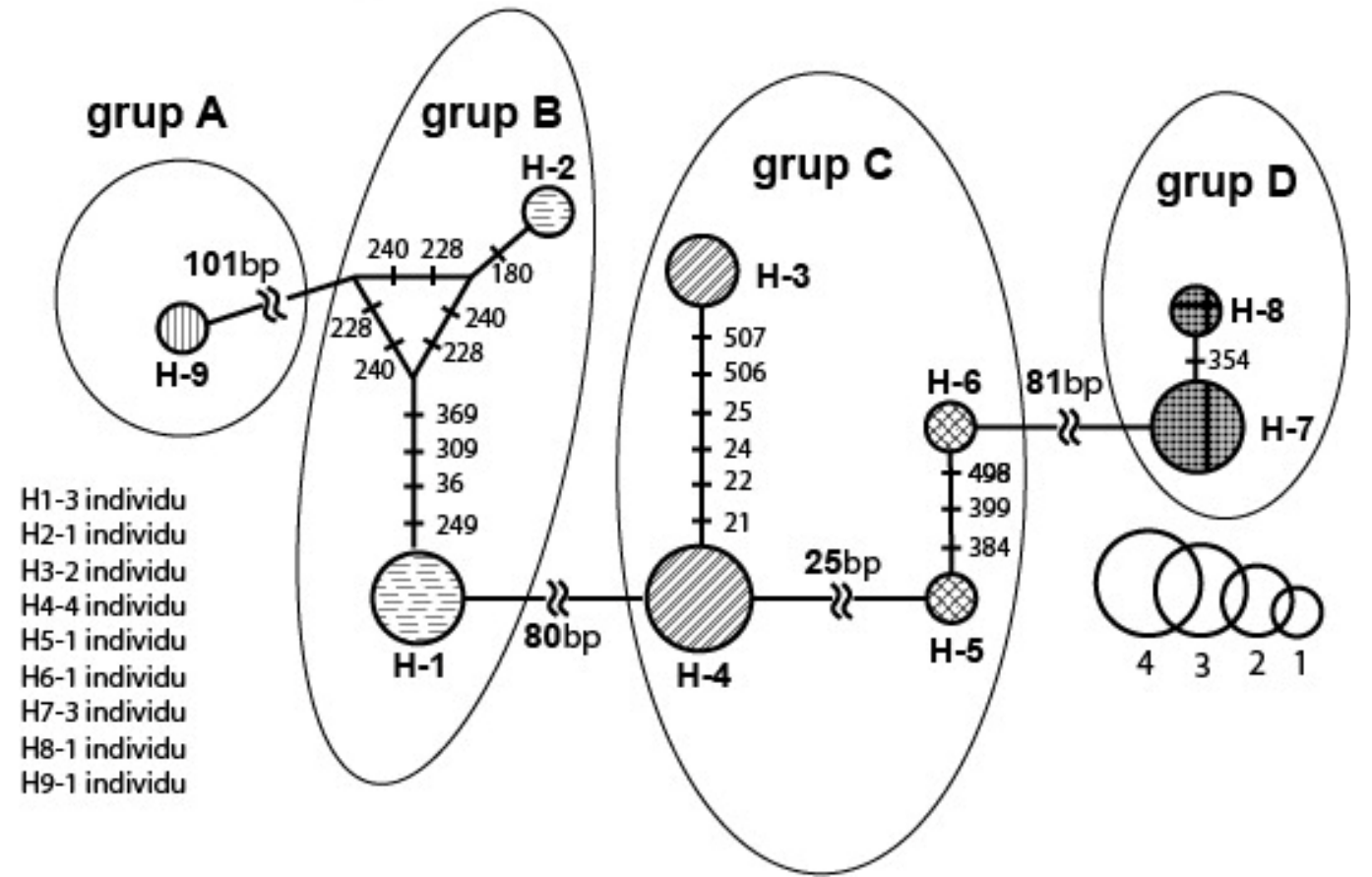

Gambar 2. Haplotype network dan distribusi geografis haplotype ikan Famili Poeciliidae A. Haplotype network dari sembilan haplotype berdasarkan sekuen gen COI. Haplotype ditunjukkan dengan bentuk lingkaran dan pola yang berbeda. Percabangan antar haplotype ditunjukkan dengan subtitusi berdasarkan posisi alignment sekuen gen COI. 
Variasi basa nukleotida tipe transisi gen COI ditemukan lebih banyak terjadi daripada transversi. Berdasarkan semua sampel Poeciliidae, jumlah variasi mutasi transisi adalah 22, sedangkan variasi basa nukleotida tipe transversi adalah sembilan atau dengan rasio 2,4 (Tabel 5). Jumlah mutasi transisi ini juga ditemukan pada DNA mitokondria seperti yang dilaporkan Lakra et al. [33] dalam penelitian mereka menunjukkan bahwa rasio transisi dengan transversi adalah 2,0 pada gen COI. Fenomena bias transisi terjadi karena adanya mutasi spontan yang melibatkan mutasi transisi jauh lebih besar daripada mutasi transversi. Kedua, seleksi alam memengaruhi bias transisi karena mutasi transisi cenderung sinonim daripada mutasi transversi [34]. Sekuen barcode gen COI menunjukkan bahwa komposisi basa nukleotida GC kurang dari AT. Komposisi basa nukleotida GC antara 42,45\%-44,06\%. Hal ini serupa dengan hasil penelitian Nugroho et al. [35] jumlah basa nukleotida AT ikan Nomei yang ditemukan di perairan Kalimantan Utara lebih banyak daripada jumlah GC. Variasi tersebut bisa dihubungkan dengan fisiologi metabolisme organisme tersebut.

Berdasarkan alignment semua sampel (sampel penelitian dengan GenBank yang tertera pada Tabel 4 menunjukkan terdapat 556 bp yang terdiri atas 31 variasi basa nukleotida dan $556 \mathrm{bp}$ basa nukleotida yang conserved. Dari keseluruhan sampel yang telah disejajarkan (alignment) ditemukan basa nukleotida yang unik (karakter basa nukleotida diagnostik/penciri) yang ditemukan pada Famili Poeciliidae yang mendiami Telaga Sari, Pasuruan. Sebagai contoh pada basa nukleotida nomer 468 terdapat tiga karakter penciri yaitu Poecilia reticulata memiliki basa nukleotia Sitosin (C), Xiphoporus hellerii (A), sedangkan Poecilia mexicana $(\mathrm{T})$. Karakter basa nukleotida diagnostik tersebut dapat digunakan untuk membedakan jenis ikan Poeciliidae. Beberapa karakter basa nukleotida dapat digunakan sebagai simple diagnostic nucleotide (sND). Sarkar et al. [36] menggunakan karakter tersebut untuk mendeskripsikan beberapa karakter yaitu shared nucleotide site (ND) atau attribute character (CA), karakter ini telah banyak digunakan [37;38]. Keberadaan basa nukleotida diagnostik merupakan syarat utama dalam identifikasi spesies menggunakan DNA Barcoding [21]. Pada penelitian ini, karakter sND sangat penting digunakan untuk mengidentifikasi Famili Poeciliidae hingga level spesies meskipun ada salah pemberian nama pada BOLD System.

Jarak genetik. Jarak genetik (Tabel 5) antara sampel dengan kerabat dekatnya dihitung menggunakan model $p$-distance. Rata-rata jarak genetik di antara Xiphoporus hellerii adalah $1,1 \%$, Poecilia reticulata $1,3 \%$ dan Poecilia mexicana $0,5 \%$. (Tabel 6). Hal ini menunjukkan bahwa keragaman genetik intragrup sangat rendah atau kurang dari $2 \%$. Nilai jarak genetik yang lebih dari $2 \%$ menunjukkan bahwa terdapat spesies yang berbeda dengan anggota grup lainnya, sebaliknya nilai jarak genetik kurang dari $3 \%$, menunjukkan grup atau klaster tersebut berasal dari spesies yang sama atau satu jenis [39]. Hasil menarik ditunjukkan pada ketiga spesies yang ditemukan telah teridentifikasi berdasarkan nilai jarak genetik intragroup. Jarak genetik antara ketiga spesies tersebut yaitu $18,7 \%$. jarak genetik ini melewati batas ambang dari standardisasi yang disebutkan oleh Hebert et al. [15], yang dapat diartikan bahwa ketiganya memang adalah spesies yang berbeda dengan variasi basa nukleotida yang tinggi di antaranya dan dapat diartikan di antara ketiga spesies tersebut memiliki keragaman genetik yang tinggi.

Hubungan kekerabatan genetik. Konstruksi topologi pohon filogenetik antara sampel dengan kerabat dekatnya (GenBank) dianalisis menggunakan metode NJ, MP dan ML dengan model perhitungan K2P (boostrap 1000 kali ulangan) (Gambar 1). Berdasarkan kladogram yang terbentuk terbagi atas dua klaster besar yang membagi atas klad Poecilia mexicana, Poecilia reticulata, Xiphoporus hellerii dengan kerabat dekatnya dari genbank. Klaster pertama membagi kelompok Xiphoporus helleriii dengan Poecilia reticulata dengan nilai bootsrap 100/99/100. Sedangkan kelompok Poecilia mexicana satu klad dengan Poecilia mexicana dari genbank. Mengacu pada nilai bootstrap masing-masing OTU berkisar antara 83 hingga 100, hal ini dapat dikatakan bahwa pengelompokan tersebut memiliki tingkat kesamaan yang tinggi. Hal berbeda tampak pada klaster kedua, dimana kelompok Xiphoporus hellerii dari genbank yang memisah klad dengan Xiphoporus hellerii sampel dengan nilai bootstrap 84 . Hal ini disebabkan karena terjadinya fenomena cyrptic species (spesies yang samar) dan telah terisolasi lama dalam geografis yang berbeda. Sebagian besar spesies ikan air tawar yang mendiami wilayah perairan 
tropis memiliki kemampuan adaptasi yang cukup tinggi, sehingga bisa terjadi perubahan karakter morfologi (radiation of morphology). Ribeiro et al. [40] menyatakan bahwa Famili Poeciliidae merupakan famili yang kompleks dengan penyebaran luas dan keragaman tinggi.

Analisis haplotype dengan menggunakan metode Median Joining Network dari delapan individu Famili Poeciliidae dengan kerabat dekatnya dianalisis dengan menggunakan program komputer Network 4.1.0.8 [30]. Median joining network membuat deskripsi variasi Famili Poeciliidae dengan kerabatnya menjadi sembilan haplotype dan terbagi menjadi empat haplogroup. Ikan Poeciliidae masuk dalam dua haplogrup yang berbeda yaitu haplotype 3 (Poecilia reticulata) dan haplotype 4 (Xiphoporus helleri) termasuk kelompok C, sedangkan haplotype 1 (Poecilia mexicana) termasuk kelompok 2. Haplotype yang berbeda dari lokasi yang sama diindikasi bahwa individu-individu yang terambil memiliki MtDNA tipe heteroplasmik. Xiphoporus hellerii yang membentuk haplotype tersendiri, meskipun berada dalam satu lokasi (Telaga Sari) (Gambar 2). Heteroplasmik merupakan sel induk yang memiliki mitokondria yang materi genetiknya mutan dan wildtype, jika terjadi segregasi replikatif, sel anak bisa memiliki materi genetik mutan dan normal [41]. Pada kasus ikan Xiphoporus hellerii tersebut kemungkinan DNA mitokondria yang terambil adalah yang heteroplasmik sehingga dihasilkan haplotype yang berbeda.

Ada beberapa informasi genetik dan status taksonomi molekuler yang telah diidentifikasi dalam penelitian ini yang dapat dijadikan sumber informasi dasar untuk studi lebih lanjut. Upaya konservasi ikan introduksi Famili Poeciliidae di Telaga Sari, Pasuruan bertujuan untuk meningkatkan kuantitas dan kualitas populasi atau individu sebagai upaya budidaya dengan benar, pengelompokan sesuai dengan spesies dan entitas genetik, serta pengembangan kriopreservasi plasma nutfah untuk keberlanjutannya. Studi genetik yang lebih luas perlu dilakukan, terutama dengan memasukkan lebih banyak sampel dan penggunaan marker molekuler yang lebih bervariasi.

\section{KESIMPULAN}

Penggunaan marka genetik DNA Barcode COI telah berhasil mengidentifikasi tiga spesies introduksi (Poecilia reticulata, Poecilia mexicana dan Xiphoporus hellerii) yang mendiami Telaga Sari, Pasuruan berdasarkan jarak genetik, variasi genetik, karakter sekuen DNA diagnostik, topologi filogenetik dan BOLD System.

\section{UCAPAN TERIMA KASIH}

Penulis mengucapkan terimakasih kepada segala pihak yang membantu selama penelitian berlangsung.

\section{DAFTAR PUSTAKA}

[1]. Lucinda PHF (2003) Family Poeciliidae, Check list of the freshwater fishes of South and Central America. Edipucrs, Porto Alegre, Brazil, pp: 555-581.

[2]. Tamaru CS, Cole B, Bailey R (2001) A manual for commercial production of the Swordtail Xiphophorus helleri. CTSA Publication/128, Honolulu, pp. 36.

[3]. Canonico GC, Arthington A, McCray JK, Thieme ML (2005) The effects of introduced tilapias on native biodiversity. Aquatic Conservation: Marine and Freshwater Ecosystems 15 (5): 463-483.

[4]. Lintermans M (2004) Human-assisted dispersal of alien freshwater fish in Australia. New Zealand Journal of Marine and Freshwater Research 38 (3): 481-501.

[5]. Koehn JD, MacKenzie RF (2004) Priority management actions for alien freshwater fish species in Australia. New Zealand Journal of Marine and Freshwater Research 38 (3): 457-472.

[6]. Lee CE (2002) Evolutionary genetics of invasive species. Trends in Ecology and Evolution 17 (8): 386- 391.

[7]. Semmens BX, Buhle ER, Salomon AK, Pattengill-Semmens CV (2004) A hotspot of non-native marine fishes: evidence for the aquarium trade as an invasion pathway. Marine Ecology Progress Series 266: 239-244.

[8]. Dudgeon D, Arhtington AH, Gessner MO, Kawabata ZI, Knowler DJ, Leveque, C. Naiman RJ, Prieur-Richards AH, Soto D, Stiassny MLJ, Sullivan CA (2006) Freshwater biodiversity: importance, threats, status and conservation challenges. Biological Review 81 (2): 163-182.

[9]. Parenti LR (1981) A phylogenetic and biogeographic analysis of Cyprinodontiformes fishes (Teleostei, 
Atherinomorpha). Nature 168 (4): 335557.

[10]. Hensen RR, Ploeg A, Fossa SA (2010) Standard names for freshwater fishes in the ornamental aquatic industry. OFI educational publication 5. Ornamental Fish International, Netherlands.

[11]. Kallman KD, Walter RB, Morizot DC, Kazianis S (2004) Two new species of Xiphophorus (Poeciliidae) from the Isthmus of Tehuantepec, Oaxaca, Mexico, with a discussion of the distribution of the $X$. clemenciae clade. American Museum Novitates 3441: 1-34.

[12]. Rahayu DA, Jannah M, Winaris N, Listyorini D (2010) The phylogenetic of Gatul fish (Xiphoporus sp.) in Sari Lake Pasuruan Regency, In Proceedings of the Association for Tropical Biology \& Conservation 2010 Meeting, Bali. Indonesia.

[13]. Frankham R, Ballau JD, Briscoes DA (2002) Introduction to conservation genetic. Cambridge University Press, Cambridge, $607 \mathrm{pp}$.

[14]. Taylor HR, Harrist WE (2012) An emergent science onthe brink of irrelevance: a review of the past 8 years of DNA barcoding. Molecular Ecology Resources 12 (3): 377-388.

[15]. Hebert PDN, Cywinska A, Ball SL, DeWaard JR (2003) Biological identifications through DNA barcodes. Proceedings of The Royal Society B: Biological Sciences 270 (1512): 313-321.

[16]. Rasmussen RS, Morrissey MT, Hebert PDN (2009) DNA barcoding of commercially important salmon and trout species (Oncorhynchus and Salmo) from North America. Journal of Agricultural and Food Chemistry 57 (18): 8379-8385.

[17]. Folmer O, Hoeh BW, Lutz R, Vrijenhoeicatk R (1994) DNA primers for amplification of mitochondrial Cytochrome-c Oxidase Subunit I from diverse Metazoan invertebrates. Molecular Marine Biology and Biotechnology 3 (5): 294-299.

[18]. Zhang DX, Hewitt GM (1997) Assesment of the universality and utility of a set of conserved mitochondrial primers in insect. Insect Molecular Biology 6 (2): 143-150.

[19]. Ward RD, Costa OF, Holmes BH, Steinke D (2008) DNA Barcoding of
Shared fish species from the North Atlantic and Australasia: Minimal divergence for most taxa, but Zeus faber and Lepidopus caudatus each probably constitute two spesies. Aquatic Biology 3: $71-78$.

[20]. Hubert N, Hanner R, Holm EM, Nicholas E (2008) Identifying Canadian freshwater fishes through DNA Barcodes. PLoS One 3 (6): e2490.

[21]. Ward RD, Zemlak TS, Innes BH, Last PR, Hebert PDN (2005) DNA Barcoding Australia's fish species. Philosophical Transactions of Royal Society B: Biological Sciences 360 (1462): 18471857.

[22]. Moreno MV, Ivanova NV, Guiterrez ME, Contreras S, Hebert PDN (2009) Probing diversity in freshwater fishes from Mexico and Guatemala with DNA barcodes. Journal of Fish Biology 74 (2): 377-402.

[23]. Rock J, Costa FO, Walker JD, North WA, Hutchinson FW, Carvalho RG (2008) DNA barcodes of fish of the Scotia Sea, Antartica indicates priorty groups for taxonomic and systematics focus. Antartic Science 20 (3): 253-262.

[24]. Collins RA, Armstrong KF, Meier R, Yi Y, Brown SDJ (2012) Barcoding and border biosecurity: Identifying Cyprinid fishes in the aquarium trade. PLoS ONE 7(1): e28381.

[25]. Kotellat M, Whitten AJ, Kartikasari SN, Wirjoatmodjo S (1993) Freshwater fishes of Western Indonesia and Sulawesi, Periplus, Hong Kong.

[26]. Robert TR (1989) The freshwater fishes of Western Borneo. California Academy of Science, California.

[27]. Ribak MP (2010) Assessing the phylogenetic utility of DNA barcoding using the New Zealand Cicada Genus Kikihia. Thesis. The University of Connecticut.

[28]. Tamura K, Stecher G, Peterson D, Filipski A, Kumar S (2013) Mega6: Molecular evolutionary genetics analysis version 6.0. Mol Biol Evol 30 (12): 27252729.

[29]. Kimura (1980) A simple method for estimating evolutionary rates of base substitutions through comparative studies of nucleotide sequences. J Mol Evol 16 (2): 111-20. 
[30]. Bandelts HJ, Forster P, Rohl A (1999) Median Joining Networks for inferring intraspesific phylogenies. Molecular Biological Evolution 16 (1): 37-48. doi: 10.1093/oxfordjournals.molbev.a026036

[31]. Buhay JE (2009) "COI-like" sequences are becoming problematic in molecular systematic and DNA barcoding studies. Journal of Crustacean Biology 29 (1): 96110.

[32]. Bensasson D, Zhang DX, Hartl DL, Hewitt GM (2001) Mitochondrial pseudogenes: Evolution's misplaced witnesses. Trends Ecology and Evolution 16 (6): 314-321.

[33]. Arthington AH (1991) Ecological and genetic impacts of introduced and translocated freshwater fishes in Australia. Canadian Journal of Fisheries and Aquatic Sciences 48 (S1): 33-43.

[34]. Lakra WS, Goswami M, Gopalakrishnan A (2009) Molecular identification and phylogenetic relationships of seven Indian Sciaenids (Pisces: Perciformes, Sciaenidae) based on 16S rRNA and cytochrome c oxidase subunit I mitochondrial genes A. Molecular Biology Reports 36 (5): 831-839.

[35]. Beckenbach AT, Thomas WK, Sohrabi H (1990) Intraspecific sequence variation in the mitochondrial genome of rainbow trout (Oncorhynchus mykiss). Genome 33 (1): 13-15.

[36]. Nugroho ED, Nawir D, Amin M, Lestari U (2017) DNA barcoding of Nomei fish (Synodontidae: Harpadon sp.) in Tarakan Island, Indonesia. AACL Bioflux 10 (6):1466-1474.

[37]. Sarkar IN, Thornton JW, Planet PJ (2002) An automated phylogenetic key for classifying homeoboxes. Molecular Phylogenetics and Evolution 24 (3): 388399.

[38]. Wong EH, Shivji MS, Hanner RH (2009) Identifying sharks with DNA barcodes: Assessing the utility of a nucleotide diagnostic approach. Molecular Ecology Resources 9: 243-256.

[39]. Wong EHK, Hanner RH (2008) DNA barcoding detects market substitution in North American seafood. Food Research International 41 (8): 828-837.

[40]. Ribeiro AO, Caires RA, Mariguela CT, Pereira LHG., Hanner R, Oliveira C, Garcia LH, Hanner R, Oliveira C (2012)
DNA barcodes identify marine fishes of Sao Paulo State, Brazil. Molecular Ecology Resources 12 (6): 1012-1020.

[41]. Nelson, JS (2006) Fishes of the world (4th ed). John Wiley \& Sons, New Jersey, pp. 624.

[42]. Esa BY, Siti, Shapor S, Siti, Khalijah, D, Khairul, Adha AR, Jeffrine RR, Soon, GT (2008) Mitochondrial DNA diversity of Tor Tambraides Valenciennes (Cyprinidae) from five natural populations in Malaysia. Zoological $\begin{array}{llll}\text { Studies } \quad 47 & \text { (3): } \quad 360-36 \text {. }\end{array}$ 